\title{
Determinan penerimaan daerah dan pertumbuhan ekonomi terhadap pengembangan ekonomi kreatif di Provinsi Jambi
}

\author{
Zamzami; Dwi Hastuti* \\ Prodi Ekonomi Pembangunan Fakultas Ekonomi dan Bisnis Universitas Jambi \\ *E-mail korespondensi: dwihastuti@unja.ac.id
}

\begin{abstract}
This study aims to analyse: (1) Contribution of regional revenue to economic growth, and analyse the development of regional revenues represented by the development of Local Own-source Revenue (PAD), General Allocation Funds (DAU), Special Allocation Funds (DAK), Revenue Sharing Funds (DBH) and also analyze the development of the economic growth rate of regencies / cities in Jambi Province. This research is intended to obtain answers to how much influence PAD, DAU, DAK, and $D B H$ influence towards the development of creative regencies / cities in Jambi Province both partially and simultaneously and from all the independent variables to be examined. The results of this study indicate that the highest growth of the processing industry is located in Tanjung Jabung Barat district and the variables that have a significant and significant influence on the processing industry in the Regency / City in Jambi Province.
\end{abstract}

Keywords: Regional Revenue, Creative Economy Development

\begin{abstract}
Abstrak
Penelitian ini bertujuan untuk menganalisis: (1) Kontribusi penerimaan daerah terhadap pertumbuhan ekonomi, serta menganalisis perkembangan penerimaan daerah yang diwakilkan dari perkembangan Pendapatan Asli Daerah (PAD), Dana Alokasi Umum (DAU), Dana Alokasi Khusus (DAK), Dana Bagi Hasil (DBH) dan juga menganalisis pengembangan laju pertumbuhan ekonomi Kabupaten/Kota di Provinsi Jambi. (2) Penelitian ini di maksudkan untuk memperoleh jawaban atas seberapa besar pengaruh PAD, DAU, DAK, dan DBH terhadap pengembangan ekonomi kreatif Kabupaten/Kota di Provinsi Jambi baik secara parsial maupun secara simultan dan dari semua variabel independen yang akan diteliti tersebut. Hasil penelitian ini menunjukkan bahwa pertumbuhan industri pengolahan tertinggi yaitu berada di kabupaten Tanjung Jabung Barat dan variabel yang mempunyai pengaruh dan signifikan terhadap industri pengolahan di Kabupaten/Kota di Provinsi Jambi.
\end{abstract}

Kata Kunci: Penerimaan Daerah, Pengembangan Ekonomi Kreatif

\section{PENDAHULUAN}

Perkembangan teknologi yang semakin canggih, kemudian diikuti dengan perubahan globalisasi yang menyebabkan masyarakat semakin dipermudah dalam memanfaatkan dunia maya atau yang lebih dikenal dengan internet. Kondisi yang demikian menyebabkan masyarakat dapat memanfaatkan fasilitas tersebut untuk mencari inspirasi bisnis, dan memperluas jaringan bisnisnya. Faktor yang menyebabkan PDB Indonesia mengalami kenaikan adalah ekspor hasil ekonomi kreatif Indonesia dengan tiga negara tujuan ekspor terbesar pada tahun 2015 yaitu negara Amerika Serikat sebesar 31,72\%, negara Jepang sebesar 6,74\% dan Taiwan sebesar 4,99\%. Sedangkan negara-negara seperti Swiss, Jerman, Singapura, Tiongkok, Hongkong, Belgia dan Inggris masih menjadi tujuan ekspor walaupun hanya sedikit. Saat ini sub 
sektor ekonomi kreatif dibedakan menjadi 16 subsektor yaitu bidang aplikasi dan game developer, arsitektur, desain interior, desain komunikasi visual, desain produk, fashion, film, animasi, dan video, fotografi, kriya, kuliner, musik, penerbitan, periklanan, seni pertunjukan, seni rupa, dan televisi dan radio. Berdasarkan hasil penelitian Awalia (2015) menunjukkan bahwa subsektor industri kreatif dengan kontribusi paling tinggi yaitu fesyen dan kerajinan. Sementara itu, subsektor dengan kontribusi terendah yaitu pasar barang seni periklanan, dan seni pertunjukan dengan kontribusi yang belum mencapai 1 persen. Kemudian dengan analisis uji kausalitas dua arah antara PDB dan ekspor industri kreatif Indonesia menunjukan bahwa PDB Industri Kreatif dan Ekspor saling mempengaruhi.

Berdasarkan hasil survei khusus ekonomi kreatif (2017) menunjukkan bahwa dari 16 sub sektor ekonomi kreatif tersebut yang menjadi sektor unggulan adalah fashion dengan tingkat 56\%, kriya sebesar 37\%, kuliner sebesar 6\%, dan yang lainnya rata-rata sekitar 1\%. Data survei ekonomi kreatif (2017) mennyatakan bahwa ekspor ekonomi kreatif Indonesia paling besar berasal dari Jawa Barat sebesar 33,56\%, diikuti oleh daerah Jawa Timur sebesar 20,85\%, Banten 15,56\%, Jawa Tengah 14,02\%, Jakarta $10,50 \%$, Kepulauan Riau 1,89\%, Bali 1,32\%, DIY 1,26\%, Sumatra Utara 0,28\%, dan Riau $0,45 \%$.

Berbagai produksi yang dihasilkan ekonomi kreatif dan didukung dengan iklim perekonomian yang berdaya saing diharapkan mampu menjadi strategi pembangunan ekonomi kedepannya (Departemen Perdagangan Repbublik Indonesia, 2008). Sebenarnya, ekonomi kreatif sudah lama tumbuh dan berkembang di masyarakat, namun secara khusus mendapat perhatian dan pembinaan yang kuat dari pemerintah baru dimulai pada era pemerintah SBY. Sekarang ini ekonomi kreatif menjadi salah satu fokus utama pemerintah untuk mendorong perkembangan ekonomi kreatif di seluruh Indonesia sehingga target pemerintah kedepannya ekonomi kreatif mampu untuk menyokong GDP di Indonesia.

Dalam pengembangan ekonomi kreatif erat kaitannya dengan kreativitas yang dilakukan secara berkelanjutan dan tidak telepas dari kemampuan sumber daya manusiannya dalam mengelola bahan baku secara efisien sebagai input kemudian mengelolahnya menjadi barang setengah jadi dan barang jadi dengan menggunakan inovasi dan teknologi. Menurut Putra (2009) mengatakan bahwa pengelolaan industri kerajinan harus dilakukan dengan efisiensi bahan baku sesuai dengan budget atau anggaran yang dimilikinya. Pengelolaan barang tersebut memiliki nilai barang yang berinilai jual yang tinggi dengan kombinasi inovasi dan kreativitas yang dimiliki oleh masing-masing individu. Dengan demikian hubungan struktur prilaku terhadap kinerja industri kreatif lebih baik dibandingan dengan industri manufaktur (Riyanto, 2009). Hasil kerativitas yang mmengedepankan keahlian individu dan innovasi sebagai tindakan yang produktif dan berkreasi dalam menghasilkan hal yang baru (Bilton, 2007). Berawal dari kreativitas seseorang yang mampu menciptakan nilai tambah yang tinggi yang kemudian melahirkan (HKI) hak kekayaan intelektual (Henry dan Anne, 2011).Selain itu, menurut Howkins (2002) dimana industri juga sangat terkait dengan aspek sosial dan budaya. Sedangkan menurut penelitian Kamil (2012) faktor yang berpengaruh terhadap kinerja industri kreatif Indonesia secara signifikan dipengaruhi oleh ukuran perusahaan, upah untuk pekerja, dan kandungan input lokal. Kemudian menurut Aldy (2016) menyatakan bahwa pertumbuhan industri berkaitan erat dengan lokasi bahan baku, lokasi pekerja trampil, dan lokasi pasar. Hal ini menjadi salah satu alasan bahwa ekonomi kreatif dapat menyerap banyak tenaga kerja. Kemmapuan perusahaan yang besar dapat melakukan efisiensi yang bebih baik dibandingan dengan perusahan kecil. Kemampuan suatu perusahaan dapat menentukan skala ekonomi yang akhirnya akan menentukan produktivitas tenaga kerja (Gunarto, 2012). Kemampuan 
kreatifitas yang berbeda-beda setiap individu dan mampu bersaing dari segi kualitas dapat menjadikan keunggulan komparatif bagi masing-masing daerah.

Menurut Triharini,dkk (2014) yang menganalisis tentang produk unggulan daerah dengan menggunakan pendekatan one village one product (OVOP) mengatakan bahwa untuk memajuakan potensi industri kecil dan kerajinan menengah sepuluh wilayah di Indonesia diperlukannya konsistensi pemerintah dan partisipasi masyarakat dalam melaksanakan dan mengawasi berjalannnya program yang ada. Harapannya dengan adanya OVOP ini dapat meningkatkan pendapatan bagi daerahnya melalui berbagai cara misalnya kunjungan turis, meningkatkan keterampilan SDM, meningkatkan penyerapan tenaga kerja dan mengurangi pengangguran. Hal ini sejalan dengan yang dikemukakan oleh Todaro (2003) yang mengatkan bahwa dengan adanya pertumbuhan ekonomi yang tinggi akan mengurangi tingkat kemiskinan, kesenjangan pendapatan, dan tingkat pengangguran

Munculnya ekonomi kreatif diharapkan mampu menjadi penopang pertumbuhan ekonomi di tahun 2025. Selain itu, ekonomi kreatif memiliki potensi yang besar dalam hal: (1) Memberikan kontribusi ekonomi yang signifikan, (2) Dapat menciptakan iklim bisnis yang positif, (3) Membangun citra dan dan identitas bangsa, (4) Mengembangkan ekonomi berbasis pada sumber daya terbarukan, (5) Menciptakan inovasi dan kreativitas yang keunggulan kompetitif suatu bangsa, dan (6) Memberikan dampak sosial yang positif yang menciptakan ide-ide baru.

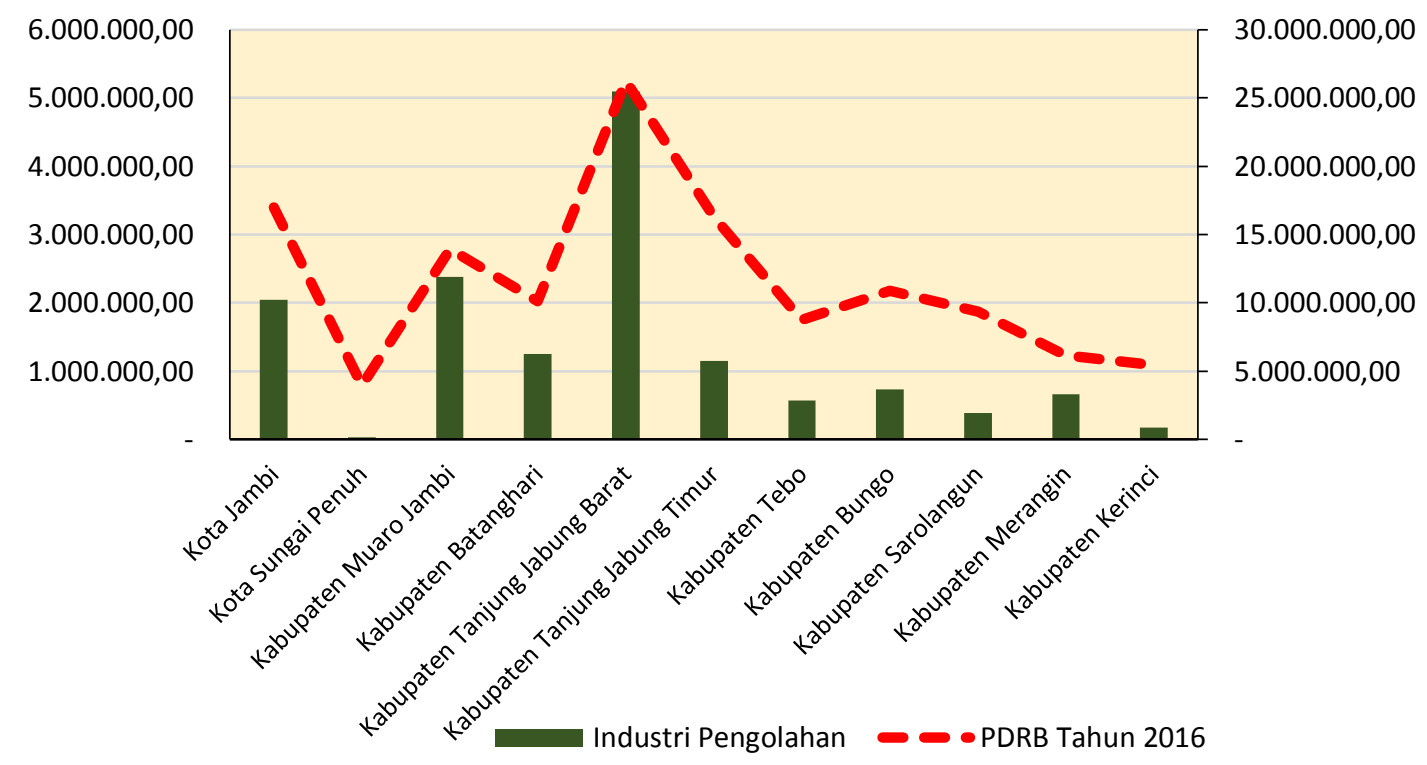

Sumber: Badan Pusat Statistik (BPS)

Gambar 1. Perkembangan industri pengolahan dan PDRB Tahun 2016

Perkembangan ekonomi kreatif terdapat di berbagai Provinsi di Indonesia. Namun karena keterbatasan informasi sehingga perkembangan ekonnomi kreatif tidak di ketahui. Menurut penelitian Indrawijaya (2016) menyatakan bahwa kinerja kerajinan di Provinsi Jambi sebesar $56 \%$ jauh lebih tinggi dibandingkan dengan sektor kuliner yang hanya $52 \%$ dan fesyen sebesar 54\%. Data ini mengambarkan bahwa ekonomi kreatif di provinsi Jambi sudah cukup berkembang sama halnya dengan daerah lain di Indonesia. Secara umum perkembangan industri pengolahan pada kabupaten/kota di Provinsi Jambi dapat terlihat pada gambar 1. Perkembangan industri pengolahan tertinggi berada pada Kabupaten Tanjung Jabung Barat. Sedangkan yang paling rendah pada Sungai Penuh. Seiring dengan meningkatnya sumberdaya manusia akan sejalan dengan 
kreativitas masyarakat untuk emngelola potensi SDA yang ada pada masing-masing daerahnya.

Pengembangan ekonomi kreatif kedepannya diharapkan dapat menjadi sumbersumber pertumbuhan seperti modal yang mengarah kepada penerimaan daerah tersebut dapat menambah modal pelaku ekonomi kreatif. Selain itu pertumbuhan penduduk dengan modal SDM yang memiliki kreativitas yang tinggi dapat membuat lapangan kerja baru dengan bantuan teknologi dan inovasi yang ada. Menurut Intan (2015) menyatakan bahwa DAU dan PAD berpengaruh signifikan terhadap belanja daerah dan memiliki hubungan positif sedangkan DAK tidak berpengaruh terhadap belanja daerah dan memiliki hubiungan negatif. Adanya belanja daerah pada masing-masing kabupaten/kota dihaharapkan dapat meningkatkan belanja pemerintah daerah dalam mengambangkan ekonomi kreatif melalui sarana dan prasaran contohnya seperti infrastruktur, pendidikan, dan modal bagi UMKM

Salah satu indikator untuk mengetahui pengembangan ekonomi kreatif di Provinsi Jambi adalah pertumbuhan ekonomi dan penerimaan daerah, mempunyai potensi yang cukup besar, namun bagaimana determinan pertumbuhan ekonomi dan penerimaan daerah dapat memberikan dampak terhadap pengembangan ekonomi kreatif di Kabupaten/Kota Provinsi Jambi. Berdasarkan uraian latar belakang diatas maka yang melatarbelakangi penulis untuk menganalisis kontribusi penerimaan daerah terhadap pertumbuhan ekonomi, serta menganalisis perkembangan penerimaan daerah yang diwakilkan dari perkembangan Pendapatan Asli Daerah (PAD), Dana Alokasi Umum (DAU), Dana Alokasi Khusus (DAK), dan Dana Bagi Hasil (DBH) Kabupaten/Kota di Provinsi Jambi.

\section{METODE}

Data yang dipergunakan dalam penelitian ini adalah data sekunder yang dikumpulkan dari kabupaten/kota di Provinsi Jambi yang meliputi data Pendapatan Asli Daerah (PAD), Dana Alokasi Umum (DAU), Dana Alokasi Khusus (DAK), Dana Bagi Hasil (DBH), Industri Pengolahan, dan pertumbuhan ekonomi PDRB masing-masing kabupaten/kota di Provinsi Jambi. Dengan menggunakan metode penelitian yang disebut metode statistik/deskriptif kuantitatif. Pengumpulan data yang dilakukan adalah menganalisa data-data sekunder dari Biro Pusat Statistik dan Biro Keuangan Provinsi Jambi selama periode tahun 2014-2016.

Pengembangan ekonomi kreatif merupakan salah satu tujuan yang menjadi perhatian pemerintah Provinsi Jambi. Salah satu aspek penting untuk mendukung strategi pengembangan ekonomi kreatif adalah dengan meningkatkan pendidikan, infrastruktur dan pemberian modal kepada masyarakat. Dengan kata lain jika penerimaan daerah tinggi apakah secara otomatis pendidikan,dan infrastuktur akan semakin baik. Untuk menanggulangi masalah ini maka diperlukannya sinergi antara pemerintah pusat dan pemerintah daerah untuk bekerjasama dalam meningkatkan pengembangan industri kreatif di masing-masing daerah.

Dalam penelitian ini teknik yang digunakan peneliti dalam menganalisis data dilakukan dengan menggunakan analisis deskriptif dan analisis inferensial. Analisis deskriptif adalah statistik yang digunakan untuk menganalisa data dengan cara mendiskripsikan atau mengambarkan data yang terkumpul untuk mengetahui penyebaran dan gambaran data (Sugiyono, 2004:169). Analisis Inverensial berkaitan dengan penarikan kesimpulan yang bersifat umum dari data yang telah disusun dan diolah (Subana, 2015:12). Analisis ini digunakan dalam penelitian ini menggunakan data panel yang merupakan gabungan data time series dan data cross section sehingga mampu menghasilkan data yang banyak

Menurut (Widarjono,2009) mengatakan bahwa data panel secara umum akan menghasilkan intersep dan slope koefisien yang berbeda pada setiap perusahaan dan 
setiap periode waktu. Metode ini digunakan untuk menguji hipotesis pada data panel. Hal ini dimaksudkan untuk menguji penerimaan daerah dan pertumbuhan ekonomi terhadap pengembangan ekonomi kreatif. Adapun persamaan regresi data panel dalam penelitian ini adalah:

$$
\begin{aligned}
\mathrm{LOG}_{-} \mathrm{INDUSTRI} & =\alpha+\beta_{1} \mathrm{LOG}_{\mathrm{it}} \mathrm{PAD} \mathrm{i}_{\mathrm{it}}+\beta_{2} \mathrm{LOG} \_\mathrm{DAK}+\beta_{3} \mathrm{LOG}_{-} \mathrm{DAU} \mathrm{U}_{\mathrm{it}}+ \\
& \beta_{4} \mathrm{LOG}_{-} \mathrm{DBH} \mathrm{it}_{\mathrm{it}}+\mathrm{e}_{\mathrm{it}}
\end{aligned}
$$

Seluruh sampel dalam penelitian ini dilakukan dengan cara transformasi logaritma, hal ini dilakukan agar setiap variabel dapat terhindar dari penyakit asumsi klasik (Ghozali 2007 dalam Maharani 2010).

\section{HASIL DAN PEMBAHASAN}

Berdasarkan hasil analisis yang dilakukan, maka hasil dan pembahasan dalam penelitian ini adalah sebagai berikut:

Uji t

Uji statistik t dilakukan untuk melihat seberapa jauh pengaruh satu variabel penjelas/independen secara individual dalam menerangkan variasi variabel dependen(Gozali, 2011:98). Dari Perhitungan yang telah dilakukan, maka diperoleh hasil t hitung sebagai berikut:

1. Variabel Pendapatan Asli Daerah (PAD) adalah sebesar 2,204330 dengan taraf signifikansi sebesar 0,0359 atau dibawah 0,05

2. Variabel Dana Alokasi Khusus (DAK) adalah sebesar 3,190919 dengan taraf signifikansi sebesar 0,0035 atau dibawah 0,05

3. Variabel Dana Alokasi Umum (DAU) adalah sebesar -2.696308 dengan taraf signifikansi sebesar 0,0117 atau dibawah 0,05

4. Variabel Dana Bagi Hasil (DBH) adalah sebesar 0,373333 dengan taraf signifikansi sebesar 0,7117 atau diatas 0,05

Berdasarkan perhitungan tersebut dapat disimpulkan bahwa $\mathrm{H}_{0}$ ditolak dan $\mathrm{H}_{a}$ diterima untuk variabel PAD, DAK, dan DAU yang artinya secara individu atau masingmasing variabel PAD, DAK dan DAU berpengaruh terhadap industri pengolahan karena probabilitas $\mathrm{t}<5 \%$. Sedangkan untuk $\mathrm{t}$ hitung pada variabel $\mathrm{DBH}$ dengan tingat probabilitas $>5 \%$ yang artinya variabel DBH secara individu tidak memiliki pengaruh yang signifikan terhadap industri pengolahan (variabel dependent).

Uji F

Hasil data panel dengan pendekatan Random Effect menggunakan Eviews 8 diperoleh nilai $\mathrm{F}$ hitung sebesar 3,143 dengan signifikansi probabilitas F-statistic sebesar 0,029 atau dibawah 0,05. Sedangkan F tabel degan taraf nyata 0,05 didapatkan angka sebesar 2,66 sehingga $\mathrm{F}$ hitung lebih besar dari $\mathrm{F}$ tabel. Dengan demikian $\mathrm{H}_{0}$ ditolak dan $\mathrm{H}_{\mathrm{a}}$ diterima dengan kata lain variabel bebas (independen) secara bersamasama mempunyai pengaruh yang signifikan terhadap variabel terikat (dependen). Dalam penelitian ini variabel PAD, DAK, DAU, dan DBH secara bersama-sama mempunyai pengaruh yang signifikan terhadap variabel industri pengolahan. 
Tabel 1 Hasil regresi linear berganda

\begin{tabular}{crrrr}
\hline \hline Variable & Coefficient & Std. Error & t-Statistic & Prob. \\
\hline \hline C & 13.74956 & 0.461076 & 29.82061 & 0.0000 \\
PAD? & 0.070594 & 0.032025 & 2.204330 & 0.0359 \\
DAK? & 0.026506 & 0.008307 & 3.190919 & 0.0035 \\
DAU? & -0.107657 & 0.039927 & -2.696308 & 0.0117 \\
DBH? & 0.005851 & 0.015672 & 0.373333 & 0.7117 \\
\hline
\end{tabular}

Sumber: Data diolah, 2017

Dari tabel diatas, maka persamaan model estimasi dalam penelitian ini adalah:

INDUSTR $_{i t}=13.7496+0.0706(P A D)_{i t}+0.0265(D A K)_{i t}-0.1077(D A U)_{i t}+0.0059(D B H)+e_{i t}$

Berdasarkan perolehan model regresi berganda pada Tabel 1 terlihat bahwa tanda koefisien paremeter masing-masing ada yang positif dan negatif. Parameter yang bertanda positif diantaranya adalah variabel PAD, DAK, dan DAU. Sedangkan parameter yang bertanda negatif adalah variabel DAU. Sementara dari 4 variabel independen yang mempengaruhi industri secara signifikan adalah variabel DAU, DAK, dan PAD. Hal ini mengambarkan bahwa jika Pendapatan Asli Daerah (PAD), Dana Alokasi Khusus (DAK) dan Dana Bagi Hasil (DBH) meningkat maka industri pengelolahan akan meningkat. Sebaliknya jika variabel jumlah PAD, dan DAK menurun maka hasil industri pengolahan juga akan menurun.

Jika DAK, DAU dan DBH dianggap tetap/tidak berubah maka kenaikan $1 \%$ PAD akan meningkatkan industri pengolahan sebanyak $0.07 \%$. Selanjutnya jika PAD, DAU dan DBH dianggap tetap/ tidak berubah maka kenaikan 1\% DAK akan meningkatkan hasil industri pengolahan sebanyak $0.027 \%$. Namun apabila nilai PAD, DAK dan DBH dianggap tetap/tidak berubah maka kenaikkan 1\% DAU akan mengurangi hasil industri pengolahan sebanyak $0.108 \%$. Sedangkan jika PAD, DAK dan DAU dianggap tetap atau tidak berubah maka kenaikkan $1 \%$ DBH akan meningkatkan hasil industri pengelolaan sebesar 0,0059. Sementara itu, jika PAD, DAK, dan DAU dianggap tetap/tidak berubah maka kenaikkan rata-rata hasil industri pengolahan adalah sebesar $13.7496 \%$.

Dengan menggunakan metode Random Effect secara langsung model industri pengolahan untuk masing- masing kabupaten/kota di Provinsi Jambi dapat dinyatakan dengan persamaan berikut:

Tabel 2 Random Effects (Cross)

\begin{tabular}{lc}
\hline & Random Effects (Cross) \\
\hline _KJ_C & 0.990950 \\
_KSP_C & -3.208331 \\
_KMJ_C & 1.246787 \\
_KBI-C & 0.614921 \\
_KTJB_C & 2.114645 \\
_KTJT-C & 0.531908 \\
_KTO_C & -0.266668 \\
_KBO_C & 0.070436 \\
_KS_C & -0.570254 \\
_KM-C & -0.066946 \\
_KK_C & -1.457449
\end{tabular}

Keterangan: Kota Jambi (KJ), Kota Sungai Penuh (KSP), Kabupaten Muaro Jambi (KMJ), Kabupaten Batanghari (KBI), Kabupaten Tanjung Jabung Barat (KTJB), Kabupaten Tanjung Jabung Timur (KTJT), Kabupaten Tebo (KTO), Kabupaten Bungo (KBO), 
Kabupaten Sarolangun (KS), Kabupaten Merangin (KM), Kabupaten Kerinci (KK)

Tabel 3 Effects Specification

\begin{tabular}{|c|c|c|c|c|}
\hline & \multicolumn{2}{|c|}{ Effects Specification } & S.D. & Rho \\
\hline $\begin{array}{l}\text { Cross-section random } \\
\text { Idiosvncratic random }\end{array}$ & & & $\begin{array}{l}1.362055 \\
0.035374\end{array}$ & $\begin{array}{l}0.9993 \\
0.0007\end{array}$ \\
\hline \multicolumn{5}{|c|}{ Weighted Statistics } \\
\hline $\begin{array}{l}\text { R-squared } \\
\text { Adjusted R-squared } \\
\text { S.E. of regression } \\
\text { F-statistic } \\
\text { Prob(F-statistic) } \\
\end{array}$ & $\begin{array}{l}0.309893 \\
0.211307 \\
0.036036 \\
3.143361 \\
0.029665 \\
\end{array}$ & \multicolumn{2}{|c|}{$\begin{array}{l}\text { Mean dependent var } \\
\text { S.D. dependent var } \\
\text { Sum squared resid } \\
\text { Durbin-Watson stat }\end{array}$} & $\begin{array}{l}0.201032 \\
0.040578 \\
0.036361 \\
1.293830\end{array}$ \\
\hline
\end{tabular}

Sumber: Data diolah, 2017

Berdasarkan data pada tabel 2 dan tabel 3 di peroleh persamaan industri pengolahan untuk setiap kabupaten/kota di Provinsi Jambi. Adapun persamaanya sebagai berikut:

INDUSTRI_KJ $=0.9910+13.7496+0.0706 * \mathrm{PAD} \_\mathrm{KJ}+0.0265 * \mathrm{DAK} \_\mathrm{KJ}-$

$$
0.1077 * \mathrm{DAU} \_\mathrm{KJ}+0.0059 * \mathrm{DBH} \_\mathrm{KJ}
$$

INDUSTRI_KSP $=-3.2083+13.7496+0.07059 * \mathrm{PAD} \_K S P+0.0265 * \mathrm{DAK} \_K S P$

$$
0.1077 * \mathrm{DAU} \_\mathrm{KSP}+0.0059 * \mathrm{DBH} \_\mathrm{KSP}
$$

INDUSTRI_KMJ $=1.2468+13.7496+0.0706 * \mathrm{PAD} \_K M J+0.0265 * \mathrm{DAK} \_K M J-$

$$
0.1077 * \text { DAU_KMJ }+0.0059 * \text { DBH_KMJ }
$$

INDUSTRI_KBI $=0.6149+13.7495+0.0706 * \mathrm{PAD}$ _KBI $+0.02651 * \mathrm{DAK}$ KBI $0.1077 *$ DAU_KBI $+0.0059 * \mathrm{DBH} \_\mathrm{KBI}$

INDUSTRI_KTJB $=2.1146+13.7496+0.0706 * \mathrm{PAD} \_K T J B+0.0266 * \mathrm{DAK}$ KTJB $0.10766 * \mathrm{DAU} \_\mathrm{KTJB}+0.0059 * \mathrm{DBH} \_\mathrm{KTJB}$

INDUSTRI_KTJT $=0.5319+13.7496+0.0706 *$ PAD_KTJT $+0.0266 *$ DAK_KTJT $0.1077 * \mathrm{DAU} \_\mathrm{KTJT}+0.0059 * \mathrm{DBH} \_\mathrm{KTJT}$

INDUSTRI_KTO $=-0.2667+13.7496+0.0706 *$ PAD_KTO $+0.0266 *$ DAK_KTO $0.1077 *$ DAU_KTO $+0.0059 *$ DBH_KTO

INDUSTRI_KBO $=0.0704+13.7496+0.0706 * \mathrm{PAD} \_\mathrm{KBO}+0.0266 * \mathrm{DAK} \_\mathrm{KBO}-$ $0.1077 * \mathrm{DAU} \_\mathrm{KBO}+0.0059 * \mathrm{DBH} \_\mathrm{KBO}$

INDUSTRI_KS $=-0.5703+13.7496+0.0706 * \mathrm{PAD} \_\mathrm{KS}+0.0266 * \mathrm{DAK} \_\mathrm{KS}-$ $0.10766 * \mathrm{DAU} \_\mathrm{KS}+0.0059 * \mathrm{DBH} \_\mathrm{KS}$

INDUSTRI_KM $=-0.0669+13.7496+0.0706 *$ PAD_KM $+0.0265 *$ DAK_KM $0.1077 * \mathrm{DAU} \_\mathrm{KM}+0.0059 * \mathrm{DBH} \_\mathrm{KM}$

INDUSTRI_KK $=-1.4574+13.7496+0.0706 *$ PAD_KK $+0.0266 *$ DAK_KK $0.1077 *$ DAU_KK $+0.0059 *$ DBH_KK

Berdasarkan hasil regresi tersebut terdapat konstanta yang negatif yaitu pada kabupaten/kota di Provinsi Jambi yaitu Kota Sungai Penuh, Kabupaten Tebo, Kabupaten Sarolangun, Kabupaten Merangin, dan Kabupaten Kerinci. Koefisien negatif artinya rata-rata kontribusi variabel lain diluar model memberikan dampak negatif 
terhadap industri pengolahan. Sedangkan Kabupaten/Kota di Provinsi Jambi seperti Kota Jambi, Kabupaten Muaro Jambi, Kabupaten Batanghari, Kabupaten Tanjung Jabung Barat, Kabupaten Tanjung Jabung Timur, dan Kabupaten Bungo. Koefisien positif artinya rata-rata kontribusi variabel lain diluar model memberikan dampak positif terhadap industri pengolahan dengan kata lain faktor - faktor lain seperti variabel PAD, DAK dan DBH akan meningkatkan hasil dari industri pengolahan di Kabupaten/Kota tersebut. Dengan demikian perlunya kebijakan-kebijakan strategis sehingga bantuan modal tepat sasaran untuk masyarakat yang memiliki UMKM.

\section{KESIMPULAN DAN SARAN}

\section{Kesimpulan}

Pertumbuhan industri pengolahan tertinggi yaitu berada di Kabupaten Tanjung Jabung Barat, selanjutnya berturut-turut Kota Jambi, Kabupaten Tanjung Jabung Timur, Kabupaten Muaro Jambi, Kabupaten Bungo, Kabupaten Bungo, Kabupaten Batanghari, Kabupaten Sarolangun, Kabupaten Tebo, Kabupaten Merangin, Kabupaten Kerinci, dan Kota Sungai Penuh. Sementara jika dilihat dari penerimaaan, dimana PAD, dan DAK tertinggi berada di daerah Kota Jambi, selanjutnya DAU tertinggi berada di Kabupaten Merangin, dan pertumbuhan DBH tertinggi berada di Kabupaten Muaro Jambi.

Variabel yang mempunyai pengaruh dan signifikan terhadap industri pengolahan di kabupaten/kota di Provinsi Jambi adalah PAD, DAK, dan DAU. Sedangkan variabel DBH pengaruhnya tidak signifikan terhadap industri pengolahan. Selain itu, PAD dan DAK mempunyai pengaruh yang positif terhadap industri pengolahan yang artinya jika terjadi kenaikan PAD dan DAK maka industri Kabupaten/Kota di Provinsi Jambi mengalami kenaikan dan sebaliknya.

\section{Saran}

Berdasarkan uraian yang telah dikemukakan pada hasil temuan empiris pada analisis data dan kesimpulan. Untuk meningkatkan hasil industri pengolahan di Kabupaten/Kota di Provinsi Jambi diperlukan sinergi kerja keras, dari semua pihak, baik pemerintah, pengusaha, dan dunia usaha. Penciptaan iklim usaha yang menunjang perkembangan usaha industri kecil, UMKM, dan pengolahan, Program bantuan berupa kredit dengan bunga yang rendah, Diversifikasi produk dengan memproduksi jenis barang yang lain sehingga akan lebih menguntungkan, Pengalokasian DAK sebaiknya lebih diarahkan ke daerah-daerah yang potensial memiliki industri pengolahan yang tinggi sehingga industri-industri dapat berkembang dengan pesat dan perlunya data khusus mengenai ekonomi kreatif sehingga pemerintah pusat dan daerah mengetahui perkembangan ekonomi kreatif setiap tahunnya. Data ini dapat menjadi dasar kebijakan yang harus dilakukan untuk pengembangan ekonomi kreatif kedepannya.

\section{DAFTAR PUSTAKA}

Aldy, R,P.(2016). Ekonomi Kreatif Pilar Pembangunan Indonesia.Nulis Buku

Awalia,Nandha,Rizki.(2015). Analisis Pertumbuhan Teknologi, Produk Domestik Bruto dan Ekspor Sektor Industri Kreatif Indonesia, Tesis Sekolah Pascasarjana Institut Pertanian Bogor:Bogor.

BPS.(2017).Data Statistik dan Hasil Survei Ekonomi Kreatif Kerjasama Badan Ekonomi Kreatif dan Badan Pusat Statistik:Jakarta. 
Departemen perdagangan Rekpublik Indonesia.(2008).Rencana Pengembangan Ekonomi Kreatif Indonesia (2009-2015). Studi Ekonomi Kreatif Indonesia: Jakarta

Devita, Andri.;Arman Delis.;Junaidi,J.(2014).Pengaruh Pendapatan Asli Daerah, Dana Alokasi Umum dan Jumlah Penduduk terhadap Belanja Daerah Kabupaten/Kota di Provinsi Jambi. Jurnal Perspektif Pembiayaan dan Pembangunan Daerah, 2(2); 63-70.

Ghozali,Imam.(2011).Aplikasi Analisis Multivariate Dengan Program SPSS.Badan Penerbit Universitas Diponegoro: Semarang

Gunanto,Kuswan.(2012). Analisis Total Factor Productivity Provinsi Jambi Tahun 1984-2011 (Dengan Metoda Growth Accounting), Tesis, Program Studi Magister Ekonomika Pembangunan FEB UGM: Yogyakarta.

Howkins.(2008).The Creative Economy. New York University, Stanford University

Indrawijaya,Sigit.(2016). Strategi Pengembangan Industri Kecil Menengah Menuju Industri Kecil Menengah Kreatif di provinsi Jambi. Universitas Jambi: Jambi

Intan,R,P.(2015).Pengaruh Dana Alokasi Umum, Dana Alokasi Khusus, dan Pendapatan Asli Daerah Terhadap Belanja Daerah Studi Empiris Pada Kabupaten/Kota Wilayah Jawa Tengah Tahun 2012-2014. Skripsi Universitas Muhammadiyah Surakarta

Junaidi.;Zulgani(2011). Peranan Sumberdaya Ekonomi dalam Pembangunan Ekonomi Daerah. Jurnal Pembangunan Daerah. Edisi III.27-33

Kamil,A.(2012).Industri Kreatif Indonesia 2000-2009: Analisis Trend dan Kinerja.Tesis Program Studi Magister Ekonomika Pembangunan FEB UGM:Yogyakarta.

Putra,Irvan.;Indra,Satria.(2009).Analisis Faktor-Faktor Yang Mempengaruhi Kinerja Industri Kerajinan di Indonesia. Skripsi, Departemen Ilmu Ekonomi, Fakultas Ekonomi dan Manajemen IPB: Bogor.

Riyanto.(2009).Industri Kreatif Indonesia 2000 dan 2005 Pendekatan Analisis Struktur, Perilaku, dan Kinerja. Skripsi Fakultas Ekonomika dan Bisnis. UGM:Yogyakarta.

Subana.;Moersetyo,R,S.(2015).Statistik Pendidikan. Cetakan Ke-5. Pustaka Setia: Bandung.

Sugiyono.(2004).Statistika untuk Penelitian,Cetakan Keenam,Penerbit Alfabeta: Bandung

Sugiyono.(2004). Metode Penelitian Bisnis. Alfabeta, CV: Bandung

Todaro, MP. (2003). Ekonomi di Dunia Ketiga, Ghalia Indonesia: Jakarta

Triharini,Meirina.;Dwinita,Larasati.;R.Susanto.(2014).Pendekatan One Village One Product (OVOP) untuk Mengembangkan Potensi Kerajinan Daerah: Studi Kasus Kerajinan Gerabah di Kecamatan Plered, Kabupaten Purwakarta. Journal of Visual Art and Design. 6(1); 29-42

Widarjono,Agus.(2009).Ekonometrika Pengantar dan Aplikasinya. Edisi Ketiga. EKONISIA:Yogyakarta. 